\title{
MODEL OF ENGINEERING EDUCATION WITH THE USE OF THE COMPETENCE-PROJECT APPROACH, ONTOLOGICAL ENGINEERING AND SMART CONTRACTS OF KNOWLEDGE COMPONENTS
}

\author{
Bulat Kubekov $^{1}$, Leonid Bobrov ${ }^{2}$, Anar Utegenova ${ }^{3}$, Vitaly Naumenko ${ }^{1}$, Raigul Alenova ${ }^{1}$ \\ ${ }^{1}$ Turan University, Department of Computer and Software Engineering, Almaty, Kazakhstan, ${ }^{2}$ Novosibirsk State University of Economics and Management, Novosibirsk, Russia, \\ ${ }^{3}$ Institute of Information and Computational Technologies CS MES, Almaty, Kazakhstan \\ Abstract. The article presents the results of research related to the use of ontological and design competence approaches for the development of knowledge \\ components and their subsequent use for designing individual trajectories of engineering education. The methodology of engineering education is \\ considered, which, together with the initiative CDIO, the project-competence model and the knowledge display in the form of ontology, can be used as the \\ main tool for modelling the propositional presentation of thought. Within the framework of the ontological approach, a knowledge specification language \\ has been developed, which allows modelling the ontologies of supporting concepts of the semantic context of educational resources and specifying them in \\ the form of knowledge expressions. The introduced formalisms and rules of the language of knowledge specification give the expressions of knowledge the \\ properties of adaptability, extensibility, easement of processing and maintenance, which is important in designing engineering education level programs. \\ This technique was tested on the material of the famous monograph by Hassan Goma "UML. Designing real-time systems, parallel and distributed \\ applications" for the project "Banking system of client-server type" and is used on classes. Expressions of knowledge, together with their interfaces, are \\ knowledge components from which individual learning trajectories are constructed.
}

Keywords: ontology, knowledge, learning

\section{MODEL EDUKACJI INŻYNIERYJNEJ Z WYKORZYSTANIEM PODEJŚCIA KOMPETENCYJNEGO, INŻYNIERII ONTOLOGICZNEJ I INTELIGENTNYCH POLĄCZEŃ SKLADNIKÓW WIEDZY}

\begin{abstract}
Streszczenie. $W$ artykule przedstawiono wyniki badań zwiazanych z wykorzystaniem podejśc kompetencyjnych ontologicznych $i$ projektowych do opracowania komponentów wiedzy i ich późniejszego wykorzystania do projektowania indywidualnych ścieżek edukacji inżynierskiej. Rozważana jest metodologia edukacji inżynierskiej, która wraz z inicjatywa CDIO, modelem kompetencji projektowych i prezentacja wiedzy w formie ontologii, może być wykorzystana jako główne narzędzie do modelowania propozycji prezentacji myśli. W ramach podejścia ontologicznego opracowano język specyfikacji wiedzy, który pozwala modelować ontologie wspierajace koncepcje semantycznego kontekstu zasobów edukacyjnych i określać je w formie wyrażeń wiedzy. Wprowadzone formalizacje i reguły języka specyfikacji wiedzy nadaja wyrażeniom wiedzy właściwości adaptowalności, rozszerzalności, łatwości przetwarzania $i$ konserwacji, co jest ważne przy projektowaniu programów inżynieryjnych. Technika ta została sprawdzona na materiale stynnej monografii Hassana Gomy "UML. Designing real-time systems, parallel and distributed applications" w projekcie "Banking system of client-server type" (,,System bankowy typu klient-serwer ") i jest wykorzystywana na zajęciach. Wyrażenia wiedzy, wraz z ich interfejsami, sq składnikami wiedzy, z których budowane są indywidualne ścieżki uczenia się.
\end{abstract}

Slowa kluczowe: ontologia, wiedza, nauka

\section{Introduction}

The innovativeness of research lies in the design and development of a new paradigm of knowledge representation based on project-competence and ontological approaches. As part of the research, new areas of scientific and methodological problems were considered, such as the development of a methodology for building knowledge components based on competence and a semantic model for the notion of educational resources, the use of concepts and standards of the worldwide CDIO initiative and the design method of engineering education: Khutorskoy (2013), Chuchalin (2016), Crowley (2001), Khutorskoy (2013) [1, 2, 9, 12].

The relevance of transferring the information base of education to a new paradigm of knowledge representation is emphasized in order to improve the efficiency and quality of education, diversification of the methods of e-pedagogy and the range of educational services, and expansion of a new educational technologies, including Smart-technologies [3, 4, 10, 11].

To display the knowledge, the ontological model O_m $=\langle\mathrm{C}, \mathrm{R}, \mathrm{F}\rangle$ is used, in which $\mathrm{C}$ is a set of concepts of educational resources; $\mathrm{R}$ is the set of relationships between concepts; $\mathrm{F}$ is a set of interpretation functions, the definitions of which are defined on the relationship between concepts in ontology. The semantic context of educational resources is modelled by the ontologies of supporting concepts, the specifications of which are represented as knowledge expressions Kubekov, et al. (2015), Kubekov, et al. (2016), Kubekov, et al. (2017) $[5,6,7,8]$.

\section{Formalisms of knowledge modelling}

Engineering education is an intellectual activity related to the analysis of educational resources, the formalization of the semantic context of resources, in the form of ontologies of supporting concepts, and their specification by expressions of knowledge.

Application of ontological model requires:

- Firstly, the holding of analysis of the structure and organization of the semantic context of the learning domain or a cognitive field of knowledge, within which the semantics and meaning of the concepts, phrases, or aggregates of phrases entering this area are most clearly and concretely identified;

- Secondly, the creation of visual-mental images, using the associative linking of the concepts and structural elements of the semantic context of the learning domain, which is necessary for the formation of an integrated system of knowledge, within a separate discipline or course;

- Thirdly, the inclusion of the interaction mechanisms of the visual-mental formations of the semantic context-learning domain, encouraging students to acquire professional and practical skills.

The process of building an ontology begins with the definition of basic abstractions of the learning domain - supporting concepts that make up the semantic context of the learning domain. Each supporting concept, being the root of an ontology, is defined by its own instances, composed of identifying and specifying concepts. 
The identifying concept is the concept of the first level of the ontology of the supporting concept, with the help of which the semantic and distinctive properties of the supporting concept is determined relative to other basic concepts of the domain of learning. The identifying concept is associated with the supporting concept by associative - semantic signs, which guarantees the uniqueness of the supporting concept in the domain of study.

A specific concept is a second-level concept of an ontology of a support concept, which, in the context of its identifying concept, configures the semantic and distinctive properties of the support concept, using typical or all sorts of combinations of child concepts with a clear and unambiguous description of the support concept.

The syntax and rules of the language of knowledge description allow us to formulate a statement about the support concept of the domain of learning and specify this statement in the form of an expression of knowledge. The operands of the expression of knowledge are identifying and concretizing concepts of the ontology of the support concept, over which the relations "composition", "aggregation" and "alternative choice" are defined.

These relationships allow displaying semantic identity between the concepts of ontology through the following definitions of the interpretation function:

Definition 1. The relation "composition" is a relation that reflects the commonality property for a child concept, and the presence of a child concept in instances of a support concept is obligatorily.

Definition 2. The relation "aggregation" is a relation in which the generality property for a child concept is reflected, and the presence of a child concept in instances of the support concept is non-obligatorily.

Definition 3. The relation "alternative choice" is a relation in which the changeability property of a child concept is reflected through the alternative choice of related concepts, relative to the child concept, in instances of the support concept.

Semantic identity and the specification of the relationship "composition" give rise to a set of obligatory specifying child concepts of a support concept. This relationship implies the use of obligatory specifying concepts only within the framework of this support concept, giving them some uniqueness.

The relation "aggregation" is a combination of obligatory and non-obligatory child concepts of the support concept, which implies the use of concrete notions not only within the framework of this support concept.

The "alternative choice" relationship is defined for various combinations of mandatory, or various combinations of mandatory and optional concepts of a support concept. For example, in this expression of knowledge: $\mathrm{Ci}<=*^{*} \mathrm{Ci} 1{ }^{*} \mathrm{Ci} 2\left({ }^{*} \mathrm{C} 1 \sim+\mathrm{C} 2\right) * \mathrm{Ci} 3+\mathrm{Ci} 4$; support concept of $\mathrm{Ci}$ is identified by a composition of mandatory $\mathrm{Ci1}, \mathrm{Ci} 2, \mathrm{Ci} 3$ and aggregation of an optional $\mathrm{Ci} 4$ child concepts, with the obligatory concept $\mathrm{Ci} 2$ defining the semantic context for the concepts of its level of concrete definition, as an alternative to choosing the mandatory $\mathrm{C} 1$, or the optional concept $\mathrm{C} 2$. In Figure 1 the ontology of the support concept $\mathrm{Ci}$ is shown:

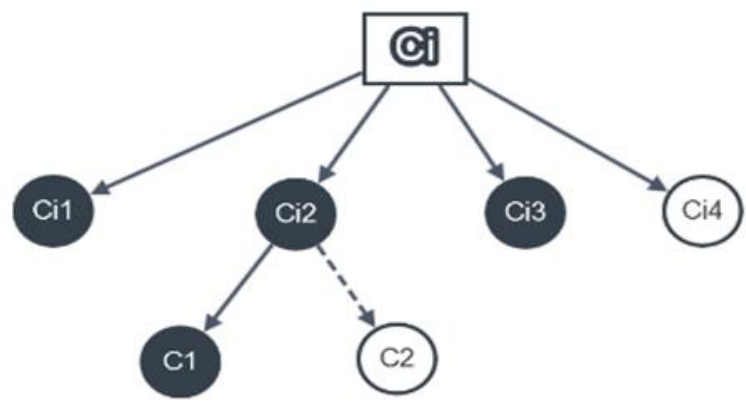

Fig. 1. The ontology of the support concept $\mathrm{Ci}$

\section{Methodology}

Educational field engineering is a technique that allows the development of educational resources based on a family of knowledge components of reuse. Reuse is one of the results of a qualitative analysis of the domain of learning and is usually synonymous with extensibility and maintenance convenience of a component system in the future.

By learning domain we will mean not only the knowledge that really belongs to the educational field, but also such knowledge that governs the development of a new educational programs and processes in this area. This is good if you can break the educational resource into common / stable and changeable parts based on differences in properties and data structure.

Therefore, the methodology is based on the project method of teaching, the implementation of which is governed by the stages of the CDIO initiative, a description of the competence models of the stages, each of which is represented by sets of supporting concepts. Further, the ontologies of supporting concepts are simulated by a system of identifying and specifying concepts and, with the help of the introduced language, their specification in the form of knowledge expressions.

The expression of knowledge ontology of the support concept thus implies the truth of the conclusion on the support concept, that is, if from the truth of the implication follows "the premise is an expression of knowledge" is true, then the same is true for the "conclusion is the support concept".

The knowledge component is the set of knowledge expressions, which has the following contract: Bertrand Meyer (2009) [9].

$$
p(K)\{K E\} q(K)
$$

where $p(K)$ is a statement, the arguments of which are mandatory competencies necessary for the student to successfully master the educational material represented by a set of expressions of knowledge $\{K E\}$. The post condition $q(K)$ is a statement, the arguments of which are the competencies that the student will have in future if he has successfully mastered the training material represented by a set of expressions of knowledge $\{K E\}$.

Thus, the knowledge component is a unit for assembling a knowledge architecture of an individualized trajectory of engineering education, and contracts are a condition for verifying the correctness of the design of such an architecture. The mechanism for documenting the knowledge architecture, specified in the interface of the constructor, must always enumerate the complete list of preconditions, which determines under what conditions it is permissible to use this or that knowledge component.

For these purposes, the definitions of the following concepts are introduced: knowledge component, component model and component environment.

Knowledge Component (KC, Knowledge Component) is a composition of knowledge expressions, which is a structural element of the environment and configuration management, and has a well-defined smart contract that actually describes the rules for implementing the knowledge component in an educational program. In other words, a knowledge component is a selected area of special knowledge required for solving certain practical problems and interacting with other knowledge components of the environment through the following parameters of a smart contract.

$$
\{P\}<K C, \text { Col, Lev }>\{Q\}
$$

The parameter $P$ is a precondition, that is, a statement in the form of a signature of the required competencies necessary for the success of the training provided for by the knowledge component $K C$. The precondition must always be satisfied when referring to the knowledge component of $K C$, otherwise the correctness of the learning result is not guaranteed.

The parameter $Q$ is a post condition, that is, an assertion in the form of a signature of competencies guaranteed to the student, when the precondition is fulfilled and the knowledge acquired by the knowledge component $K C$ is successful. 
Post condition $Q$ determines the results of the implementation of the knowledge component $K C$, that is, the correctness of the required competencies obtained by students. As for the knowledge components that are called, the fulfilment of their post conditions must be guaranteed by themselves, therefore the causing knowledge component $K C$ can rely on them in its implementation.

When implementing a smart contract knowledge component, its preconditions can be weakened, and the post conditions - only strengthen. This means that a knowledge component can fulfil its responsibilities for a wider range of restrictions than is required by its precondition, and, as a result of its implementation, fulfil more stringent restrictions than is required by its post-condition.

Thus, a knowledge component can be considered a unit of deployment of the knowledge architecture of an educational program, which can join an educational program if it contains all knowledge components on which it depends, or is removed from the educational program and then those that depend on it can stop working.

The following parameters of the smart contract are: Levparameter, which sets limits on the level of complexity of the competencies provided for in the pre- and post-conditions of the knowledge component; $\mathrm{Col}$ is a parameter specifying references to knowledge components of the educational environment that are involved in the implementation of this knowledge component. The parameters Lev and Col, thus, determine the infrastructure that allows to take into account the individual characteristics of the student, and the knowledge components, to interact according to certain rules.

A component model is a smart contract of a knowledge component, the rules for its configuration and implementation, in accordance with the scenario of interaction with other knowledge components of the educational environment. It can be said that the component model defines a "language" in which knowledge components interact with each other according to a specific scenario.

For the work of knowledge components, a certain set of basic services and services of the educational environment is necessary, ensuring the functioning of knowledge components. Such a set of services and services, together with the component model supported with their help, is called the component environment.

\section{Results}

"Banking system of client-server type" was considered as a project: Hassan G. (2014) [3]. For each stage of the CDIO, competency models have been defined, which were compositions of professional, basic and additional competencies. The semantic context of all stages was represented by fifty-four support concepts, each of which was modelled as an ontology. The specification of the support concept was represented by the expression of knowledge. Any support concept, being the root peak of an ontology, was represented by two levels of identifying and specifying concepts.

For example, the professional competencies of the Design phase are represented by six support concepts, of which we consider the support concept of C6 - The detailed program design.

The ontology of the support concept C6 is represented by the following hierarchical structure of concepts:

* C61 is the detailed design of composite tasks containing nested objects. This identifying concept is the semantic context of the second level of specification, including the following child concepts: $* \mathrm{C} 1$ is the relationship between tasks and classes; $* \mathrm{C} 2$ is the division of responsibilities between tasks and classes; $* \mathrm{C} 3$ is the temporal grouping and device interface objects; * $\mathrm{C} 4$ is the management grouping and objects that hide information.

* C62 is the synchronization of access to classes. This identifying concept is the semantic context of the second level of specification, including the following child concepts: * $\mathrm{C} 1$ is the synchronization of access to the data store by the method of mutual exclusion; * $\mathrm{C} 2$ is the synchronization of access to the data warehouse by the method of several readers and writers.
* C63 is the design of classes - connectors for inter-task communications. This identifying concept is the semantic context of the second level of specification, including the following child concepts: * $\mathrm{C} 1$ is the designing of a class i.e. a connector that implements a message queue; ${ }^{*} \mathrm{C} 2$ is the designing of a class i.e. a connector that implements a message buffer; ${ }^{*} \mathrm{C} 3$ is the designing of a class i.e. a connector that implements a message buffer with an answer; $* \mathrm{C} 4$ is the designing of a group of cooperative tasks using objects - connectors.

+ C64 is the logic of ordering events in the specification of the behaviour of tasks.

The expression of knowledge of this support concept is as follows:

$$
\begin{gathered}
C 6<=* C 6.1(* C 1 * C 2 * C 3 * C 4) * C 6.2(* C 1 * C 2) * \\
C 6.3(* C 1 * C 2 * C 3 * C 4)+C 6.4
\end{gathered}
$$

and the corresponding graph is presented in Figure 2.

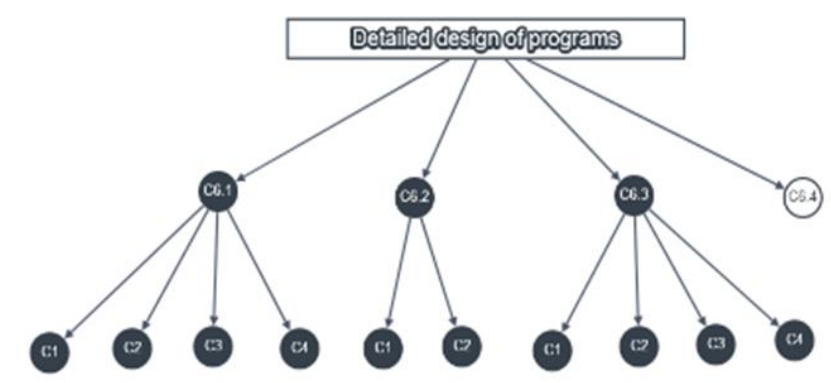

Fig. 2. The graph of the ontology of the support concept C6

Thus, the model of engineering education determines the development of ontologies of support concepts of educational resources and their specification in the form of expressions of knowledge. Knowledge expressions, along with their interfaces, serve to design knowledge components from which individual learning paths are constructed.

This model of engineering education has been tested and is used in the educational process for students of the specialty "Software Engineering", Turan University.

\section{Conclusions}

In fact, the considered model of engineering training provides transition to a new educational paradigm of knowledge presentation and organization, in improving the management mechanism, through adaptive planning and implementation of educational programs. The model can have a significant impact on both economic and social aspects related to education, which include: the massive introduction of open educational courses and tools of Smart-technologies in educational institutions for the new (network) generation, as well as a qualitative change in the content of education and teaching methods. The concepts and mechanisms of the model will contribute to the development of flexible learning in an interactive educational environment, personalizing learning, free access to educational content, and increasing the effectiveness of teaching and information technologies aimed at developing the epistemological function of the competence approach.

Developed interactive educational smart-environment provides the following opportunities for its use:

1. In the case of the formation of disciplines of the curriculum of the modular educational program of the specialty "Computing equipment and software", and first of all the disciplines of the "Mandatory module in the specialty" and "Module in the specialty" based on the SES RK and the Model curriculum. This opportunity provides the head of the department, together with an expert in the person of the IT industry:

- to formulate requirements for the content of educational content of the disciplines of the module;

- regulate and manage the educational content of disciplines; 
- to adapt educational content in accordance with the development of new technologies and software development tools;

- to control the relevance of the content of educationalmethodical complexes of disciplines to the formed requirements.

An additional expert function will also be the analysis of the current state of technologies and software engineering tools and the introduction of appropriate changes in the knowledge components of the interactive educational smart environment repository.

2. In the case of the formation of the disciplines "Mandatory module in the specialty" and "Module in the specialty", but with a focus on project-oriented learning technology, an interactive educational smart-environment allows you to plan the necessary disciplines of the CDIO stages, and to form their knowledge trends, in accordance with competence model of each of the stages of the CDIO. At the same time, the distribution of disciplines by stages of the CDIO, respectively - by semesters of the module, and their purpose should be due to the need to develop knowledge and achieve skills in areas related to subject engineering, commonality and variability analysis - as the basis of the entire design. In this way, abstractions are created by the human mind, with the choice of platform and software and, directly, the development of project software and its maintenance.

3. In the case of the formation of the knowledge trend of the individual learning path of the student, in accordance with the required learning scenario and the use of project-oriented learning technology. At the same time, the learning scenario will be formed on the basis of the competence model competency signatures of each of the stages of the CDIO, and the knowledge components will be configured using the smart contract parameters.

\section{Acknowledgements}

The work has been supported by a grant from the Ministry of Education and Science of the Republic of Kazakhstan.

\section{Prof. Bulat Kubekov \\ e-mail: b.kubekov@mail.ru}

Professor of the University of Turan, candidate of technical sciences project supervisor. Honoured Worker of Education of the Republic of Kazakhstan, Academician of the International Academy of Information.

ORCID ID: 0000-0001-8658-3742

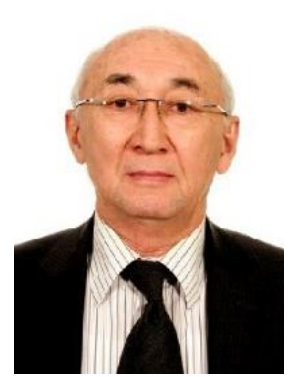

\section{Prof. Leonid Bobrov}

e-mail: bobrov@nsuem.ru

Professor, Department of Business Informatics, Doctor of Technical Sciences, Associate Professor, Senior Researcher at Novosibirsk State University of Economics and Management.

ORCID ID: 0000-0001-5071-1116

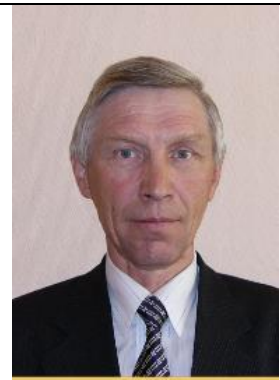

Ph.D. Anar Utegenova

e-mail: utegenova77@mail.ru

Ph.D. specialty 6D070400 - Computer Science and Software, Satbayev University, Researcher Institute of Information and Computational Technologies CS MES.

\section{References}

[1] Chuchalin A., Malmqvist J., Tayurskaya M.: Professional development of Russian HEIs' management and faculty in CDIO standards application. European Journal of Engineering Education 41(4)/2016, 426-437.

[2] Crowley E.: CDIO Program: Description of the aims and objectives of bachelor's engineering education. CDIO Report 1/2001.

[3] Hassan G.: UML Design of the systems of real time parallel and the distributed applications: The lane with English. DMK Press, Moscov 2014.

[4] Khutorskoy A.: Competence approach in training. Scientific and methodical manual. Publishing house "Eidos", Moscov 2013.

[5] Kubekov B., Beyer, Ditmar, Utegenova A., Zhaksybaeva N.: Innovative paradigm of education of knowledge - competency form based on ontology. Journal of theoretical and applied information technology 95(21)/2005, 58595868 .

[6] Kubekov B., Kuandykova J., Utepbergenov I., Utegenova A.: Application of the conceptual model of knowledge for formalization of concepts of educational content. 9th International Conference on Application of Information and Communication Technologies AICT2015, 2015, 294-306.

[7] Kubekov B., Utepbergenov I.: The use of multiparadigm approach to knowledge modeling. 7th International Conference on Education and New Learning Technologies, 2015.

[8] Kubekov B.: Educational components formation technology for the planned CDIO SYLLABUS education. 9th Annual International Conference of Education, Research and Innovation - ICERI2016 2016, 6139-6145.

[9] Meyer B.: Touch of Class. Learning to Program Well with Objects and Contracts. Springer Verlag, 2009.

[10] Saule K., Indira U., Aleksander B., Gulnaz Z., Zhanl M., Madina I., Györök G.: Development of the Information and Analytical System in the Control of Management of University Scientific and Educational Activities. Acta Polytechnica Hungarica 15(4)/2018, 27-44
[DOI: 10.12700/APH.15.4.2018.4.2].

[11] Uvalieva I., Smailova S.: Development of decision support system to control the quality of education. 2014 IEEE 8th International Conference on Application of Information and Communication Technologies (AICT) 2014 [DOI: 10.1109/ICAICT.2014.7036018]

[12] Yue J., Rui H.: Application of MOOC in CDIO integrated teaching pattem: A case study of software engineering major. 12th International Conference on Computer Science and Education (ICCSE) 2017, 324-327.

\begin{abstract}
M.Sc. Vitaly Naumenko
e-mail: naumenko.v5@mail.ru

Master of Technical Sciences of the University of Turan specialty Computing and software. Doctoral Ph.D. in Computer Engineering and Software, International IT University.
\end{abstract}

\section{ORCID ID: 0000-0003-2783-7348}

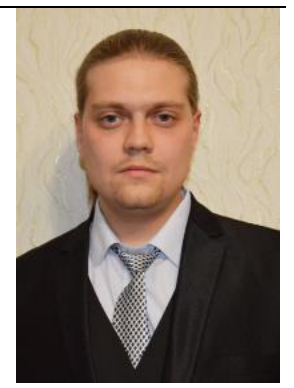

\section{M.Sc. Raigul Alenova \\ e-mail: raya.alenova@bk.ru}

Master of Technical Sciences of the University of Turan specialty Computing and software. Doctoral Ph.D. in Information Technology, International IT University.

ORCID ID: 0000-0001-5402-6327

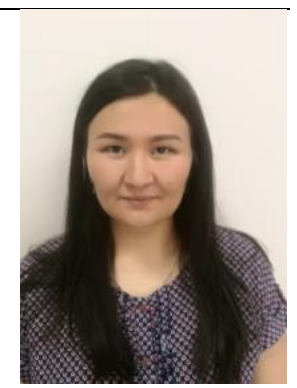

otrzymano/received: 30.05 .2019 przyjęto do druku/accepted: 15.06 .2019 